\title{
バッチ式デシカントシステムの空気調湿・調温性能に関する実験的検討 コジェネレーション排熱利用バッチ式デシカント外気処理システムの開発（その2） \\ EXPERIMENTAL EVALUATION OF THE PERFORMANCE OF BATCH TYPE DESICCANT SYSTEM
}

Development of batch type desiccant air-conditioning system using cogenerated hot water (Part 2)

\author{
朴 炳 龍*, 李 時 桓**, 加藤信介 ${ }^{* * *}$, 市川 徹***, 工月 良太 太 $^{* * * *}$ \\ Beungyong PARK, Sihwan LEE, Shinsuke KATO, \\ Toru ICHIKAWA and Ryota KUZUKI
}

\begin{abstract}
The central thrust of this study involves developing a new desiccant-based energy recovery system useful for effective humidity control and featuring integrated design and analysis. The system heat source uses unutilized energy, heated water from solar panels and cool water from cooling towers. It consists of two air-water heat exchangers with adsorbent material coated on the fins and employs directly-heated desorption or directly-cooled adsorption for absorbent material created from the effective reuse of adsorbent materials. This paper describes the adsorption/desorption characteristics and performance of the air-water heat exchanger using the coating absorption material. Measurements involving the moist air being passed into the air-water heat exchanger via the coating of adsorbent material were conducted under various conditions. Consequently, the air-conditioning performance of the proposed system was found to be strongly dependent on the water temperature under constant air condition. The operating cycle of the system was also determined. The measured results make efficient use of the basic data from the numerical analysis model.
\end{abstract}

\section{Keywords : Cogeneration, Batch-type desiccant system, System performance, Measurement コジェネレーション, バッチ式デシカントシステム, システムの性能, 実験}

\section{1. はじめに}

本研究は低温排熱を利用するバッチ式デシカント外気処理システ ム (以下, 提案システム) を提案し, 建築への適用性評価を行って いる。固体吸着剂を用いたデシカントシステムは, シリカゲル，ゼ オライトなどの固体の吸着剤を加熱冷却するサーマルサイクルを連 続的に行うことにより, 継続的に処理空気中の水蒸気を吸・脱着し, 除湿もしくは加湿を行う。吸・脱着の過程で液水が現れないので, 微生物污染のリスクを低くすることが可能で有り, 衛生的なシステ ムとなる。加熱泠却のサーマルサイクルを行う過程で加熱源と冷却 熱源の熱エネルギーを必要とする。排熱を利用するなど効率的な運 用を行うためには, 加熱源と冷却熱源が, デシカントシステム動作 時の環境温度（室温もしくは外気温）と温度差が少なくても効率的 に作動すること, サーマルサイクルの過程で生じる加熱源から泠却 熱源に移行寸る熱量を少なくすることが重要になる。

筆者ら 1)は低温排熱などの自然エネルギーで駆動されるバッチ式 デシカント外気処理システムを提案した。また，提案システムの技 術的適用可能性を検討するために建築の各換気方式注 1)について性 能比較を行い, 室内温熱環境の改善効果および省エネルギー効果を
報告した。特に提案システムの数值解析用簡易モデル（性能推定値 利用）を用いて提案システムの性能把握を行い，その性能がさまざ まなパラメータ（室内外温・湿度）によって大きく異なることを確 認した。

本研究で提案したシステムを実用化するには，既報で考慮しえな かったさまざまなパラメータである各地域の気候条件・建物の用 途・熱源などのシステムへの依存性を踏まえた総合的な適用可能性 を検討する必要がある。このような個別条件に関して逐一検討する のは時間的, 費用的な制約から容易ではない。したがって, 数值解 析による検討が有効であると考える。数值解析により提案システム の適用性を検討するためには，実運転時におけるシステムの性能の 再現性が数值解析モデルに確保されなければならない。そのために さまざまな環境条件下におけるシステム性能と数值解析モデルの解 析結果との比較により, 数值解析モデルの解析精度を高める作業が 必要である。

以上より本報では, 提案システムの精密な数值解析モデルを作成 するためにシステムの性能に関する基礎データを取得することを目 的とする。ここでは下記の二つの実験を行う。

\footnotetext{
* 東京大学生产技術研究所 協力研究員 $\cdot$ 工博 (東京理科大学 助教)

** 東京大学生産技術研究所 特任研究員 $\cdot$ 工博 (東京理科大学 助教)

*** 東京大学生产技術研究所 教授.工博

**** 東京ガス(侏)エネルギー企画部 研究員
}

Cooperative Researcher, Institute of Industrial Science, The University of Tokyo, Ph. D. (Assistant Prof., Tokyo University of Science)

Project Researcher, Institute of Industrial Science, The University of Tokyo, Ph. D.

(Assistant Prof., Tokyo University of Science)

Prof., Institute of Industrial Science, The University of Tokyo, Ph. D.

Researcher, Energy Sales and Service Planning, Dept., Tokyo Gas Co., Ltd. 
(1) 提案システムの構成要素である吸着剤が塗布された水・空気式 熱交換器（以下，熱交換器）に供給する冷・温水投入温度と流量の 変化による水蒸気吸着と脱着性能の評価実験をそれぞれ実施した場 合の性能評価を行い, 吸・脱着特性と調湿量の関係および吸・脱着 完了時間の検討の上, 提案システム連続運転に必要なサイクル時間 の最適值を求める。
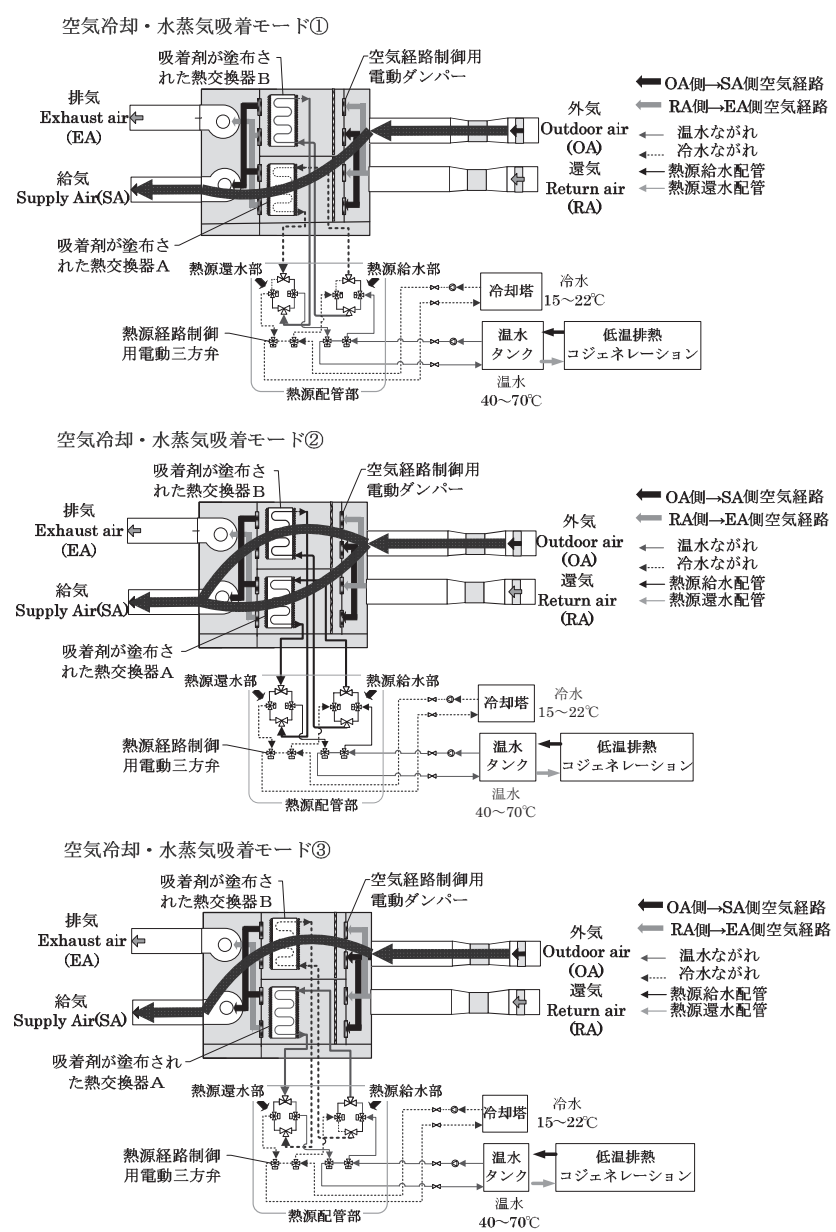

(a) 空気冷却・水蒸気吸着モード
(2) 一定のサイクル（交互に繰り返し）でシステムを連続運転した 場合, 空気冷却・水蒸気吸着 (除湿) 性能および空気加熱・水蒸気 脱着 (加湿) を外気温・湿度の変化により検討する。

\section{2. 提案システムの概要}

図 1 に低温排熱を利用するバッチ式デシカントシステムの構成図

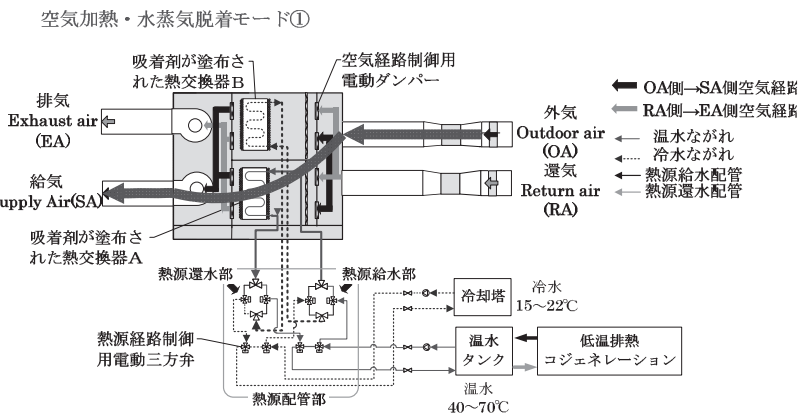
空気加熱・水蒸気脱着モード(2)

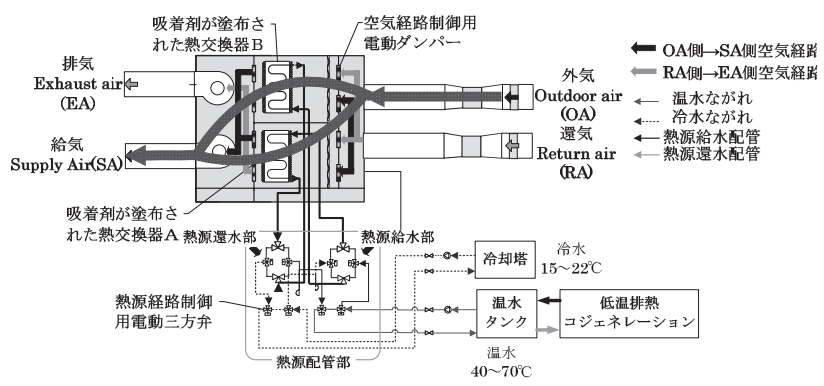

空気加熱・水蒸気脱着モード(3)

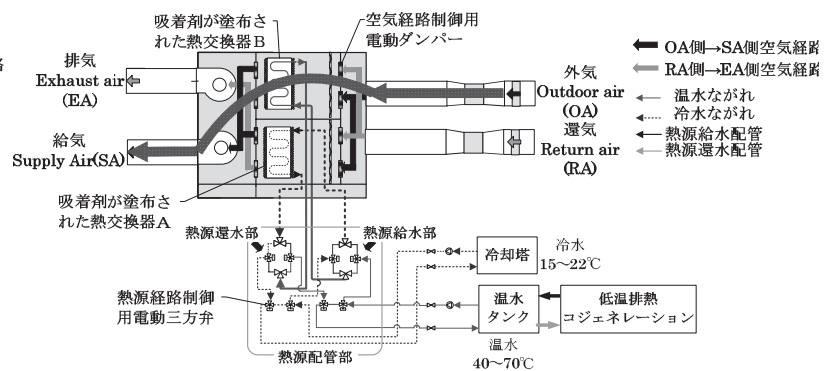

(b) 空気加熱・水蒸気脱着モード

図 1 低温排熱を利用寸るバッチ式デシカントシステムの構成図と各運転モード

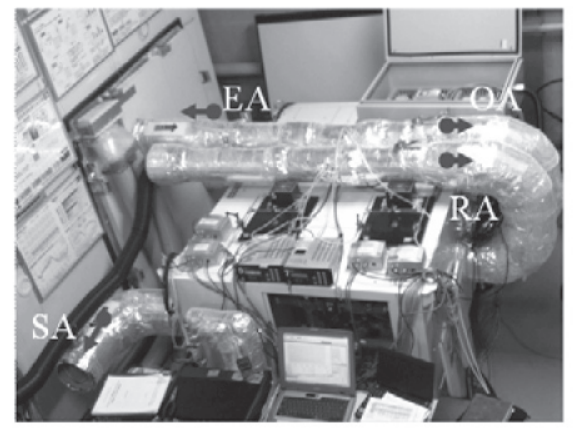

写真 1 提案システムの外観

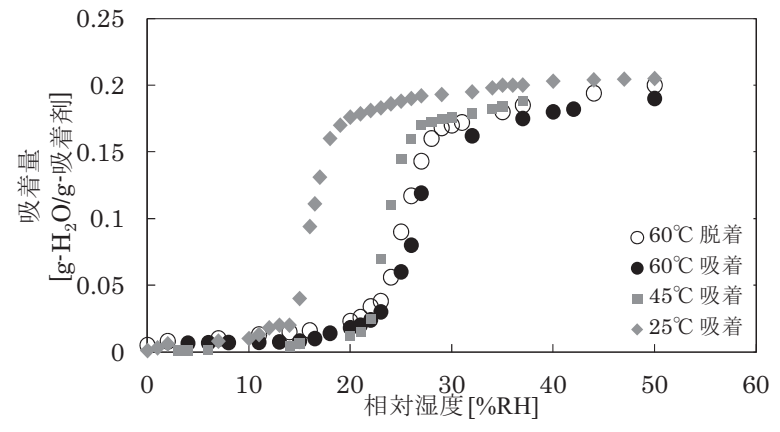

図 2 吸着剂の水蒸気吸着等温線 2) 
と空気冷却・水蒸気吸着モード, 空気加熱・水蒸気脱着モードの空 気と熱源水の流れを示す。表 1 亿提案システムの構成要素の概要お よび写真 1 に提案システムの外観を示す。提案システムの外形寸法 は横幅(W) $1,800 \times$ 奥行き(L) $1,250 \times$ 高さ (H) $800 \mathrm{~mm}$ である。提案 システムは, 熱交換器 2 台と共に, ファン 2 台, 空気経路制御用電 動ダンパー8台, 熱源経路制御用電動三方弁 8 台で構成されている。 熱交換器の寸法は横幅 $(\mathrm{W}) 264.0 \times$ 奥行き(L) $400.0 \times$ 高さ(H) 65.2 $\mathrm{mm}$ であり, 伝熱面積は $5.50 \mathrm{~m}^{2}$ (管部面積 $0.29 \mathrm{~m}^{2}$, フィン部面積 $\left.5.20 \mathrm{~m}^{2}\right)$ である。熱交換器のアルミフィン上部の表面には, ゼオラ イト系の水蒸気吸着剂（質量 $0.98 \mathrm{~kg}$, 熱容量 $0.805 \mathrm{~kJ} /(\mathrm{kg} \cdot \mathrm{K})(303$ K の場合）2） が塗布されている。提案システムは除湿側と加湿側 でそれぞれの空気経路が分離されており，熱交換器に冷水・温水を 投入し，サーマルサイクルによる水蒸気の吸着・脱着をおこなう。 それにより，外気 (outdoor air, OA) を空気冷却・水蒸気吸着（除 湿側）もしくは空気加熱・水蒸気脱着（加湿側）することが可能に なる。

空気冷却・水蒸気吸着モード（図 1(a)）におけるサーマルサイク ルの空気と熱源水の流れで空気の状態変化をみると除湿側（外気 $\rightarrow$ 熱交換器 $\mathrm{A} \rightarrow$ 給気）では外気を椧却・水蒸気吸着し加湿側（還気 $\rightarrow$ 熱交換器 $\mathrm{B} \rightarrow$ 排気）では還気（return air，RA）を加熱・水蒸気脱 着する。既存のヒートポンプ式デシカントシステム 3 )の駆動原理も 同様であるが，提案したシステムは空気加熱・水蒸気脱着（加湿） にコジェネレーションや燃料電池などで得られた低温排熱を用いた 温水 $\left(40 \sim 70^{\circ} \mathrm{C}\right)$ を活用するという特徵がある。また, 空気冷却・ 水蒸気吸着 (除湿) にはクーリングタワー (cooling tower) による 冷水 $\left(10 \sim 22^{\circ} \mathrm{C}\right)$ もしくは, 冬期には熱交換器を通過する空気 (外 気）を活用する。図 2 に熱交換器に塗布された吸着剤の $25{ }^{\circ} \mathrm{C}$ (吸 着), $45{ }^{\circ} \mathrm{C}$ (吸着), $65{ }^{\circ} \mathrm{C}$ の水蒸気吸・脱着等温線を示寸2)。吸着 特性は $10 \% \mathrm{RH}$ 以下の相対湿度（空気の水蒸気圧/飽和水蒸気圧） 域では水蒸気をほとんど吸着せず，相対湿度 $15 \% \mathrm{RH}$ 付近から急激 に吸着し始め, 狭い相対湿度範囲で多量の水蒸気が吸着されるとい う特性がある2)

\section{3. 提案システムの性能評価方法}

本研究では, 提案システムの精密な数值解析モデルを作成するた

表 1 提案システムの構成概要

\begin{tabular}{|c|c|c|c|}
\hline 項目 & \multicolumn{2}{|r|}{ 内 容 } & \multirow[t]{2}{*}{ 数量 } \\
\hline 本体 & 寸法 & $\begin{array}{l}\text { 横幅(W) } 1,800 \times \text { 奥行き(L) 1,250 } \\
\text { ×高さ(H) } 800 \mathrm{~mm}\end{array}$ & \\
\hline \multirow{5}{*}{$\begin{array}{l}\text { 吸着剤が } \\
\text { 塗布された } \\
\text { 熱交換器 }\end{array}$} & 寸法 & $\begin{array}{l}\text { 横幅 }(\mathrm{W}) 264.0 \times \text { 奥行き }(\mathrm{L}) 400.0 \\
\text { ×高さ(H) } 65.2 \mathrm{~mm}\end{array}$ & \multirow{5}{*}{2 台 } \\
\hline & 銅管外径 & $9.53 \mathrm{~mm}$ & \\
\hline & 吸着剤 & 0.98 kg (ゼオライト系水蒸気吸着材) & \\
\hline & 伝熱面積 & $5.50 \mathrm{~m}^{2}$ (管部: 0.29 , フィン部 : 5.20 ) & \\
\hline & $\begin{array}{l}\text { アルミ } \\
\text { フィン }\end{array}$ & ピッチ : $1.80 \mathrm{~mm}$, 厚み : $0.12 \mathrm{~mm}$ & \\
\hline 送風機 & \multicolumn{2}{|c|}{ 風量 : $500 \mathrm{~m}^{3} / \mathrm{h}$} & 2 台 \\
\hline 電動ダンパー & \multicolumn{2}{|c|}{ 寸法 : $\varphi 200$ mm (空気経路切り替え) } & 8 台 \\
\hline 電動三方弁 & \multicolumn{2}{|c|}{ 寸法 : $\varphi 20$ mm (熱源経路切り替え) } & 8 台 \\
\hline
\end{tabular}

め基礎デー夕を実験により取得する。そのためにさまざまなパラメ 一夕（室内外温・湿度，風量，投入冷温水温度，投入流量，サーマ ルサイクル）の変化による水蒸気吸・脱着特性, 空気冷却・水蒸気 吸着性能および空気加熱・水蒸気脱着性能について評価をおこなう。 風量は日本工業規格 (JIS B 8628) 4) に基づき評価測定をおこなう。 それぞれの評価項目は以下の式に基づいて算出する。

・空気の密度補正

$$
\rho_{\text {air }}=\rho_{0} \times \frac{273.15}{273.15+T}
$$

ここに, $\rho_{\text {air }}$ は空気の温度補正した密度 $\left[\mathrm{kg} / \mathrm{m}^{3}\right], \rho_{0}$ は 1 気圧 $0^{\circ} \mathrm{C}$ 気体の密度 $1.293\left[\mathrm{~kg} / \mathrm{m}^{3}\right], T$ は風量測定点の空気温度 $\left[{ }^{\circ} \mathrm{C}\right]$ である。 ・風量の算出

$$
Q_{s}=A \times V \times 3600=A \times \alpha \times \sqrt{\frac{2}{\rho_{\text {air }}} \times \Delta P} \times 3600
$$

ここに， $Q_{S}$ は測定風量 $\left[\mathrm{m}^{3} / \mathrm{h}\right], A$ は測定配管の断面積 $\left[\mathrm{m}^{2}\right], a$ は流量係数 [-]（ここでは流量計測に用いたエアロアイの流量係数 0.77 [-]を使用)，Vは気流速度 $[\mathrm{m} / \mathrm{s}], \Delta P$ : 差圧 $[\mathrm{Pa}]$ である。

·有効換気量の算出

有効換気量は空気流路の実際換気量であり, 測定風量 $\left(Q_{S}\right)$ と漏 えい量の差から算出する。

(a) 二酸化炭素移行率

二酸化炭素移行率（式(3)）は実証実験装置（提案システム）の漏 気，空気流路内の隙間による別経路への漏気を含めた，漏気量（式 4）を算出するために求める。本検討では提案システムで適用され ている吸着剤によって吸着もしくは脱着された二酸化炭素による影 響は無視する。ここでは, RA-EA 側固定流路の間に RA 側（空気入 口で濃度発生点）で二酸化炭素を流し，RA 側と OA 側（流路外の 大気濃度基準点）の濃度差と EA 側（空気出口濃度点）と OA 側の 濃度差の比から二酸化炭素移行率を算出する。

$$
E_{G}=\left(\mathrm{C}_{E A}-\mathrm{C}_{O A}\right) /\left(\mathrm{C}_{R A}-\mathrm{C}_{O A}\right) \times 100
$$

(b) 漏えい量

$$
q=Q_{S} \times\left(E_{G} / 100\right)
$$

(c) 有効換気量

$$
Q_{E}=Q_{S}-q=Q_{S}-\left\{\left(Q_{S} \times\left(E_{G} / 100\right)\right\}\right.
$$

ここに， $E_{G}$ は二酸化炭素移行率 $[\%], C_{E A}$ は給気側の二酸化炭素 濃度, $C_{O A}$ は外気側の二酸化炭素濃度, $C_{R A}$ は還気側の二酸化炭素 濃度， $q$ はシステムの漏えい量 $\left[\mathrm{m}^{3} / \mathrm{h}\right] ， Q_{S}$ は測定風量 $\left[\mathrm{m}^{3} / \mathrm{h}\right] ， Q_{E}$ は有効換気量 $\left[\mathrm{m}^{3} / \mathrm{h}\right]$ である。

・空気側の熱収支

$$
\begin{gathered}
Q_{\text {Air__sensible }}=\int_{0}^{t}\left\{\frac{c_{p} \times \rho_{\text {air }} \times Q_{E}}{3600} \times\left(T_{\text {in }}-T_{\text {out }}\right)\right\} \\
Q_{\text {Air_latent }}=\int_{0}^{t}\left\{\frac{h_{s} \times \rho_{\text {air }} \times Q_{E}}{3600} \times\left(X_{\text {in }}-X_{\text {out }}\right)\right\} \\
Q_{\text {Air }}=Q_{\text {Air_sensible }}+Q_{\text {Air_latent }}
\end{gathered}
$$

ここに，QAir_sensible は空気処理顕熱量 $[\mathrm{kW}] ， Q_{\text {Air_latent }}$ は空気処理潜 熱量 $\left[\mathrm{kW}, Q_{A i r}\right.$ は空気処理全熱量 $[\mathrm{kW}], c_{p}$ は空気の定圧比熱 $\left(25^{\circ} \mathrm{C}\right.$, $1 \mathrm{~atm}$ 基準 $1.006[\mathrm{~kJ} /(\mathrm{kg} \cdot \mathrm{K})]) ， T_{\text {in }}$ は入口側空気の温度 $\left[{ }^{\circ} \mathrm{C}\right] ， T_{\text {out }}$ は 出口側空気の温度 $\left[{ }^{\circ} \mathrm{C}\right], h_{s}$ は水蒸気の蒸発潜熱 $[\mathrm{kJ} / \mathrm{kg}]\left(20^{\circ} \mathrm{C}, 1 \mathrm{~atm}\right.$ 基準 $2,454 \mathrm{~kJ} / \mathrm{kg}$ )， $X_{\text {in }}$ は入口側空気の絶対湿度 [ $\mathrm{kg}$ (vapor) $/ \mathrm{kg}$ (air)], $X_{\text {out }}$ は出口側空気の絶対湿度 $[\mathrm{kg}$ (vapor) $/ \mathrm{kg}$ (air)]である。 


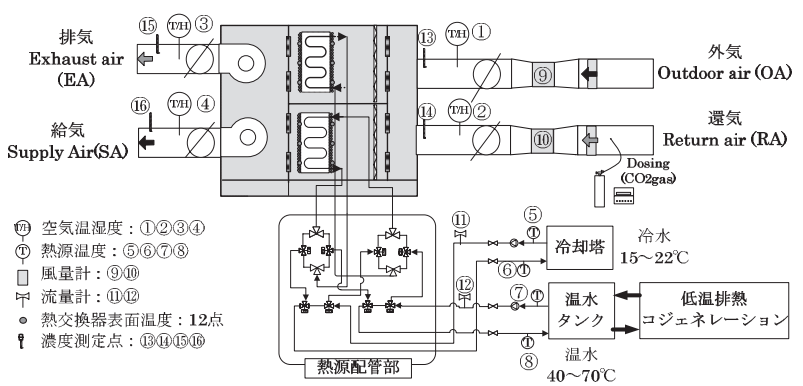

図 3 提案システムの測定点

- 熱源の加湿側と除湿側の投入熱量

$$
\begin{aligned}
& Q_{\text {Hot_water }}=\int_{0}^{t} c_{w} \times G_{h} \times\left(T_{\text {win }}-T_{\text {wout }}\right) \\
& Q_{\text {Cool_water }}=\int_{0}^{t} c_{w} \times G_{c} \times\left(T_{\text {cin }}-T_{\text {cout }}\right)
\end{aligned}
$$

ここに，QHot_water は加湿側の投入熱量 $[\mathrm{kW}] ， Q_{\text {Cool_water }}$ は除湿側 の投入熱量 $[\mathrm{kW}], c_{W}$ は水の定圧比熱 $\left(25^{\circ} \mathrm{C}, 1 \mathrm{~atm}\right.$ 基準, $4.18[\mathrm{~kJ} /$ $(\mathrm{kg} \cdot \mathrm{K})]), G_{h}$ は加湿側の水の流量 $[\mathrm{kg} / \mathrm{s}], G_{c}$ は除湿側の水の流量 $[\mathrm{kg} / \mathrm{s}], T_{\text {win }}$ は加湿側の流入水の温度 $\left[{ }^{\circ} \mathrm{C}\right], T_{\text {wout }}$ は加湿側の還水温 度 $\left[{ }^{\circ} \mathrm{C}\right], T_{\text {cin }}$ は除湿側の流入水の温度 $\left[{ }^{\circ} \mathrm{C}\right], T_{\text {cout }}$ は除湿側の還水温 度 $\left[{ }^{\circ} \mathrm{C}\right]$ である。

-成績係数 (coefficient of performance, COP)

COP は外気側から投入された空気処理全熱量 / 加湿側・除湿側 の投入熱量で計算する。

$$
\mathrm{COP}=Q_{\text {air }} /\left(Q_{\text {Hot_water }}+Q_{\text {Cool_water }}\right)
$$

ここに, COP はシステムの成績係数 [-]である。

\section{4. 吸着剂が塗布された熱交換器の検討}

\section{1 実験概要}

実験は千葉県習志野市侏朝日工業社技術研究所で実施する。提案 システム内の熱交換器へ投入する熱源条件の変化に対する水蒸気の 吸・脱着特性について検討する。ペアで構成されている熱交換器の 一方のみを実験対象とする。実験装置は空気の経路を還気側 (return air，RA）から排気（exhaust air，EA）側の方向に固定し（空気経 路制御用電動ダンパー切り替えなし), RA 側から給気 (supply air, SA）した空気が電気ヒータ, 冷水コイル, 電熱式蒸気加湿器などを 通過することで温・湿度制御ができるように構成する。OA 側から SA 側への空気経路はダンパーを閉状態にしてファンも駆動しなか った。表 2 と図 3 亿測定項目および各測定点を示す。風量はピトー 管式丸型エアロアイ (WETMASTER 社) を測定点(9), (10)設置し, 高精度差圧トランスデューサ (MKS 社, バラトロン) を用いて測 定する。空気の温・湿度はVAISALA 社製の測温抵抗体（RTD）セ ンサー (空気温度, 計測範囲 $-20 \sim 80^{\circ} \mathrm{C}$, 精度 $\pm 0.1^{\circ} \mathrm{C}$ ) と高分子 静電容量式センサー (空気湿度, 計測範囲 $0 \sim 100 \%$, 精度 $\pm 1 \%$ at 20 ${ }^{\circ} \mathrm{C}$ DB）を用いた。温湿度センサーの測定点位置は，予備計測とし て行われたダクト内の高さ別の測定（JIS 規格 A1431）に基づいて 定めた。ダクト内において 10 点の計測を行い, 平均値と同じ高さ を測定点位置とした。システムの気密性, 有効換気量の検討では一 定発生法を用いて測定する。トレーサガス (二酸化炭素) を RA 側

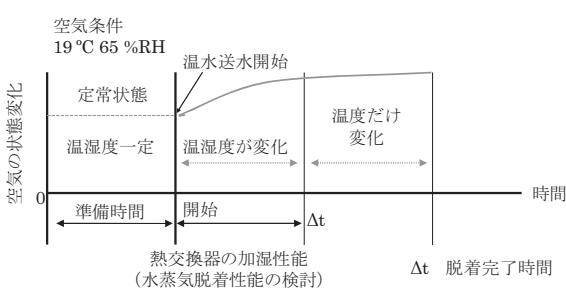

（a）空気加熱・水蒸気脱着モードの実験ながれ

空気条件

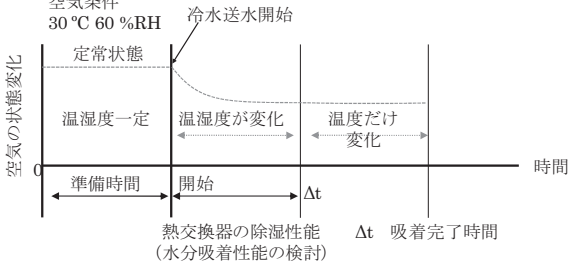

(b) 空気冷却・水蒸気吸着モードの実験ながれ

\begin{tabular}{|c|c|c|}
\hline 項目 & 機器 & 測定点 \\
\hline 空気温湿度 & \begin{tabular}{|c} 
温度 : 測温抵抗体センサー \\
湿度 : 高分子静電容量式センサー
\end{tabular} & (1), (2), (3), (4) \\
\hline 表面温度 & $\mathrm{T}$ 型熱電対 線径 : $0.2 \mathrm{~mm}$ & 熱交換器前・後 \\
\hline 冷温水温度 & 3 線式白金測温抵抗体 & (5), (6), (7), (8) \\
\hline 風量 & $\begin{array}{c}\text { 丸型エアロアイ（ピトー管式） } \\
+ \text { 差圧計 }\end{array}$ & (9), (10) \\
\hline 流量 & $\begin{array}{c}\text { 流量計 }(2.5 \sim 100 \text { l/min }) \\
\text { 電極非接液型電磁式流量センサー }\end{array}$ & (11), (12) \\
\hline $\begin{array}{c}\text { 気密性（漏えい量） } \\
\text { 有効換気量 }\end{array}$ & $\begin{array}{c}\text { マルチガスモニタ } \\
\text { (二酸化炭素) }\end{array}$ & (13), (14), (15), (16) \\
\hline データ & 高速型多点分散データロガー & - \\
\hline
\end{tabular}

図 4 各運転モードにおける実験ながれ

表 2 測定項目・測定機器・測定点

\begin{tabular}{|c|c|c|c|c|c|}
\hline ケース & 温水温度 & 流量 & ケース & 温水温度 & 流量 \\
\hline ケース 1 & \multirow{3}{*}{$40{ }^{\circ} \mathrm{C}$} & $0.18 \mathrm{~kg} / \mathrm{s}$ & ケース 7 & \multirow{3}{*}{$60{ }^{\circ} \mathrm{C}$} & $0.18 \mathrm{~kg} / \mathrm{s}$ \\
\hline ケース 2 & & $0.33 \mathrm{~kg} / \mathrm{s}$ & ケース 8 & & $0.33 \mathrm{~kg} / \mathrm{s}$ \\
\hline ケース 3 & & $0.50 \mathrm{~kg} / \mathrm{s}$ & ケース 9 & & $0.50 \mathrm{~kg} / \mathrm{s}$ \\
\hline ケース 4 & \multirow{3}{*}{$50{ }^{\circ} \mathrm{C}$} & $0.18 \mathrm{~kg} / \mathrm{s}$ & ケース 10 & \multirow{3}{*}{$70^{\circ} \mathrm{C}$} & $0.18 \mathrm{~kg} / \mathrm{s}$ \\
\hline ケース 5 & & $0.33 \mathrm{~kg} / \mathrm{s}$ & ケース 11 & & $0.33 \mathrm{~kg} / \mathrm{s}$ \\
\hline ケース 6 & & $0.50 \mathrm{~kg} / \mathrm{s}$ & ケース 12 & & $0.50 \mathrm{~kg} / \mathrm{s}$ \\
\hline 空気温・湿度 & \multicolumn{5}{|c|}{$19^{\circ} \mathrm{C}, \quad 65 \% \mathrm{RH}, \quad 8.9 \mathrm{~g} / \mathrm{kg}(\mathrm{DA})$} \\
\hline 風量 & \multicolumn{5}{|c|}{$500 \mathrm{~m}^{3} / \mathrm{h}$, 熱交換器面風速 $1.32 \mathrm{~m} / \mathrm{s}$} \\
\hline
\end{tabular}

表 3 空気加熱・水蒸気脱着実験モードにおける実験ケース

\begin{tabular}{|c|c|c|c|c|c|}
\hline ケース & 冷水温度 & 流量 & ケース & 冷水温度 & 流量 \\
\hline ケース $\mathrm{A}$ & \multirow{3}{*}{$26^{\circ} \mathrm{C}$} & $0.18 \mathrm{~kg} / \mathrm{s}$ & ケース G & \multirow{3}{*}{$22{ }^{\circ} \mathrm{C}$} & $0.18 \mathrm{~kg} / \mathrm{s}$ \\
\hline ケース B & & $0.33 \mathrm{~kg} / \mathrm{s}$ & ケース $\mathrm{H}$ & & $0.33 \mathrm{~kg} / \mathrm{s}$ \\
\hline ケース $\mathrm{C}$ & & $0.50 \mathrm{~kg} / \mathrm{s}$ & ケース I & & $0.50 \mathrm{~kg} / \mathrm{s}$ \\
\hline ケース D & \multirow{3}{*}{$24{ }^{\circ} \mathrm{C}$} & $0.18 \mathrm{~kg} / \mathrm{s}$ & \multirow[t]{3}{*}{$\gamma$} & & \\
\hline ケース $\mathrm{E}$ & & $0.33 \mathrm{~kg} / \mathrm{s}$ & & & \\
\hline ケース $\mathrm{F}$ & & $0.50 \mathrm{~kg} / \mathrm{s}$ & & & \\
\hline 空気温・湿度 & \multicolumn{5}{|c|}{$30^{\circ} \mathrm{C}, \quad 60 \% \mathrm{RH}, \quad 16.2 \mathrm{~g} / \mathrm{kg}(\mathrm{DA}) \rightarrow$ 露点温度 $21.4^{\circ} \mathrm{Cdp}$} \\
\hline 風量 & \multicolumn{5}{|c|}{$500 \mathrm{~m}^{3} / \mathrm{h}$, 熱交換器面風速 $1.32 \mathrm{~m} / \mathrm{s}$} \\
\hline
\end{tabular}

表 4 空気冷却・水蒸気吸着実験モードにおける実験ケース 


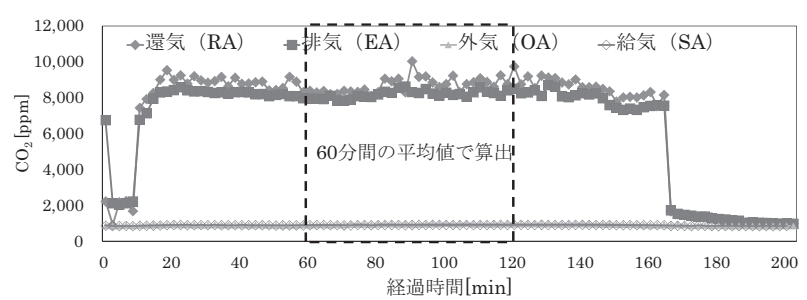

(a) 熱交換器 $\mathrm{A}$ を通過時の各点の濃度測定結果

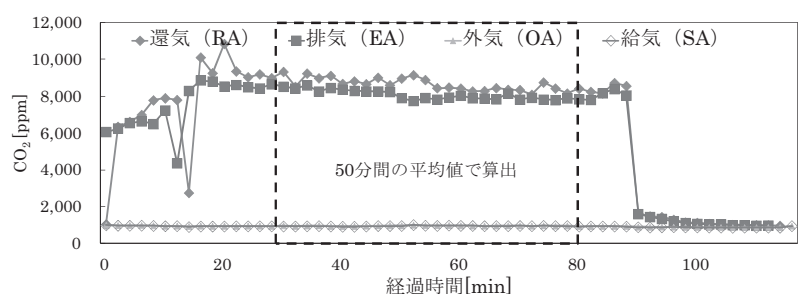

(b) 熱交換器 $\mathrm{B}$ を通過時の各点の濃度測定結果

図 5 各測定点における二酸化炭素濃度測定結果

の入口に散布し，マルチガスモニタとマルチポイントサンプラ （INNOVA 社）を用いて測定点(1)，(2)，(3)，(4)のガス濃度分析をお こなう。提案システムの連続運転（RA-EA 側ファンと OA-SA 側フ アン稼動）では各経路の空気入口（図 3 の(13) と(14)点）の圧力差がゼ ロになるように補助ダンパーを調節し，各経路に同一な風量が流れ るようにインバータ制御をおこなう。熱源条件による熱交換器の特 性検討では, 熱交換器へ投入する熱源なしの条件に関して空気の風 量変化 $\left(250 \mathrm{~m}^{3} / \mathrm{h}, 500 \mathrm{~m}^{3} / \mathrm{h}\right)$ による空気温度・絶対湿度変化およ び水蒸気吸・脱着特性の検討をおこなう。実験準備室のそのままの 空気を RA 側に供給し，EA 側から排気し長期間検討寸る。

熱源あり条件の検討では空気加熱・水蒸気脱着モード (図 4(a)), 空気泠却・水蒸気吸着モード（図 4(b)）の 2 パターンに分け, 投入 する空気の温・湿度が定常状態になってから熱交換器に熱源水（温 水もしくは冷水）を供給し, 熱交換器前・後の空気の温・湿度変化 を一定時間（吸・脱着完了時間）の間隔で測定寸る。図 4 に各運転 モードにおける実験のながれを示す。表 3 に熱交換器の空気加熱・ 水蒸気脱着モードにおける実験ケース（全 12 ケース）を示す。表 4 に熱交換器の空気冷却・水蒸気吸着モードにおける実験ケース（全 9 ケース)を示す。ダクトの周囲にグラスウール保温材(厚さ $30 \mathrm{~mm}$, 熱伝導率 $\left.4.3 \times 10^{-2} \mathrm{~W} /(\mathrm{m} \cdot \mathrm{K})\right)$, 熱交換器周辺の本体部分もスポンジ シート型断熱材（厚さ $30 \mathrm{~mm}$, 熱伝導率 $5.0 \times 10^{-2} \mathrm{~W} /(\mathrm{m} \cdot \mathrm{K})$ ) を設 置し装置外と流路間との断熱を確保した。

\section{2 熱交換器の特性検討結果}

\subsection{1 システムの気密性と有効換気量の検討結果}

$\mathrm{RA}$ 側の空気が熱交換器 $\mathrm{A}$ を通過する場合と熱交換器 $\mathrm{B}$ を通過 する場合の各測定点の浱度測定結果を図 $5(\mathrm{a})$, ( b) に示す。風量 500 $\mathrm{m}^{3} / \mathrm{h}$ (図 3 の囵) の条件において熱交換器 $\mathrm{A}$ を通過した空気経路 の二酸化炭素移動率は $0.40 \%$, 漏えい量は $2.0 \mathrm{~m}^{3} / \mathrm{h}$ であり, 有効 換気量は $498.0 \mathrm{~m}^{3} / \mathrm{h}$ である。熱交換器 $\mathrm{B}$ を通過した空気経路の二 酸化炭素移動率は $0.12 \%$, 漏えい量は $0.6 \mathrm{~m}^{3} / \mathrm{h}$ であり, 有効換気 量は $499.4 \mathrm{~m}^{3} / \mathrm{h}$ である。以上の結果から熱交換器 $\mathrm{A}$ を通過する空 気経路と熱交換器 $\mathrm{B}$ を通過する空気経路は分離されて固定経路（還

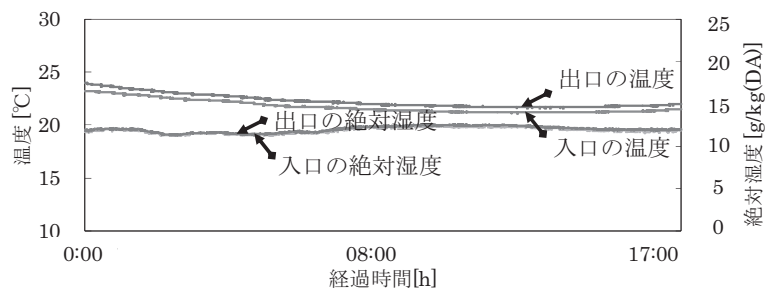

(a) 風量 $250 \mathrm{~m}^{3} / \mathrm{h}$ における空気温・湿度変化（熱源なし）

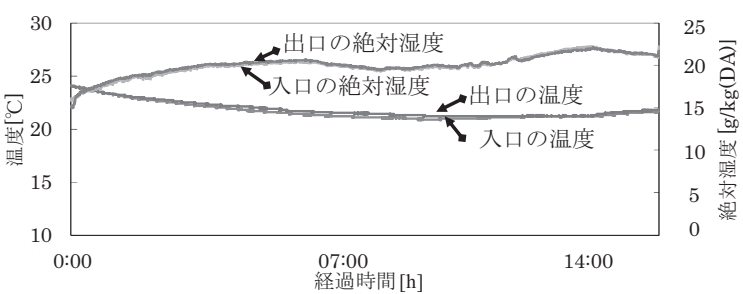

(b) 風量 $500 \mathrm{~m}^{3} / \mathrm{h}$ における空気温・湿度変化（熱源なし）

図 6 空気風量変化における熱交換器の吸・脱着特性

気 $\rightarrow$ 熱交換器 $\mathrm{A} \rightarrow$ 排気, 還気 $\rightarrow$ 熱交換器 $\mathrm{B} \rightarrow$ 排気）では気密製作さ れたと判断される。

\section{2 .2 空気風量変化における熱交換器の吸・脱着特性の検討結果}

図 6 に空気風量変化による空気の温・湿度変化の測定結果を示寸。 風量は $250 \mathrm{~m}^{3} / \mathrm{h}, 500 \mathrm{~m}^{3} / \mathrm{h}$ 条件, 熱源は供給しないという条件で 長期間測定した結果, 風量 $250 \mathrm{~m} 3 / \mathrm{h}$ （測定時間 : 約 18 時間）の空 気の出入口 $(\mathrm{RA} \rightarrow \mathrm{EA})$ の温度差は平均 $0.5{ }^{\circ} \mathrm{C}$, 湿度差は平均 0.1 $\mathrm{g} / \mathrm{kg}(\mathrm{DA})$ で非常に小さかった。風量 $500 \mathrm{~m}^{3} / \mathrm{h}$ （測定時間 : 約 25 時 間）の空気の出入口の温度差は平均 $0.4{ }^{\circ} \mathrm{C}$, 湿度差は平均 0.2 $\mathrm{g} / \mathrm{kg}(\mathrm{DA})$ である。実験の開始後に入出口の空気絶対湿度はほぼ一定 となり, 吸着剤と空気が平衡状態になったと考えられる。しかし, 入口空気の湿度を変動させて行っても湿度差は見られなかった。以 上のことから吸着剂と空気が平衡状態になるとこれ以上の吸着はで きなくなる。また, ある時間の平衡状態より低い絶対湿度が投入さ れでも水蒸気脱着は見られなかった。つまり吸着剂に吸着された水 蒸気を脱着するためには吸着力以上の力（熱など）を掛ける必要が あると考えられる。また, 温度差に関してはセンサーの誤差とファ ンの発熱によって $\mathrm{EA}$ 側の温度が約 $0.5{ }^{\circ} \mathrm{C}$ 上昇した注 2 。ここでは, 二つの風量に関して検討したが, より広範囲の風量変化に対して検 討が必要と考えられる。

\section{2 .3 熱源条件による熱交換器の吸・脱着特性の検討（熱源有り）} (1) 空気の状態変化

図 7 に空気温度 $19^{\circ} \mathrm{C}$, 相対湿度 $65 \% \mathrm{RH}$, 空気風量 $500 \mathrm{~m}^{3} / \mathrm{h}$, 供給温水流量 $0.50 \mathrm{~kg} / \mathrm{s}$ の設定条件下で, 温水温度を $40^{\circ} \mathrm{C}, 50^{\circ} \mathrm{C}$, $60{ }^{\circ} \mathrm{C}, 70^{\circ} \mathrm{C}$ (ケース $\left.3,6,9,12\right)$ に変化させた場合の空気加熱・ 水蒸気脱着モードにおける空気温度と絶対湿度の測定結果を示寸。 実験開始と同時に熱交換器に温水を投入すると, 吸着剤からの水 蒸気の脱着が行われるものの, 時間経過に伴い水蒸気脱着量（加湿 量）が徐々に減少した。空気湿度は実験開始後 60 秒 〜 180 秒の間 に大きく変化しているが，420 秒後には湿度変化が見られなくなっ た。これは吸着剤から空気中への水蒸気の脱着が完了したと考えら 
れる。脱着現象の約 $90 \%$ 以上（420 秒基準の積分量）が経過時間 360 秒間以内に発生した (図 7(a))。空気温度は脱着が起こるととも に上昇し，脱着完了後には約 $34 \sim 50{ }^{\circ} \mathrm{C}$ に達した（図 7(b))。これ らの結果から投入熱量は実験開始から脱着完了まで空気加熱・水蒸 気脱着に使用されているが，脱着完了後には全ての投入熱量は流入

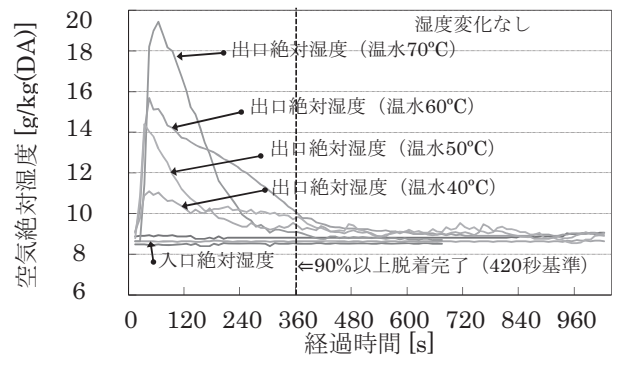

(a) 空気絶対湿度変化
空気を加熱したと考えられる。

図 8 に空気温度 $30{ }^{\circ} \mathrm{C}$, 相対湿度 $60 \% \mathrm{RH}$, 空気風量 $500 \mathrm{~m}^{3} / \mathrm{h}$, 供給冷水流量 $0.50 \mathrm{~kg} / \mathrm{s}$ の設定条件下で, 冷水温度を $26^{\circ} \mathrm{C}, 24^{\circ} \mathrm{C}$, $22{ }^{\circ} \mathrm{C}($ ケース C, F, I) に変化させた場合の空気泠却・水蒸気吸着 モードにおける空気温度と絶対湿度の測定結果を示す。熱交換器に

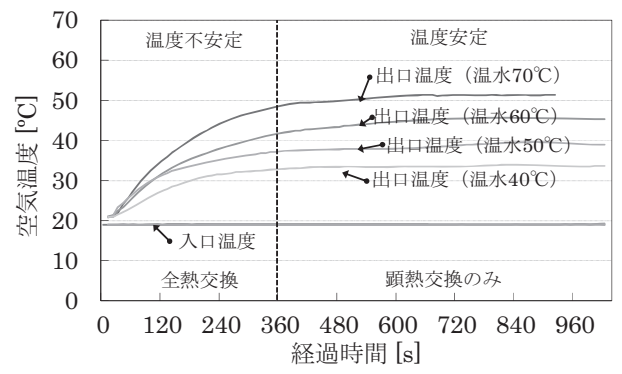

(b) 空気温度変化

図 7 空気加熱・水蒸気脱着モードにおける空気の温・湿度変化

※温水流量 $0.50 \mathrm{~kg} / \mathrm{s}$ で, $19{ }^{\circ} \mathrm{C}, 65 \% \mathrm{RH}$ の空気 $500 \mathrm{~m}^{3} / \mathrm{h}$ が供給された場合

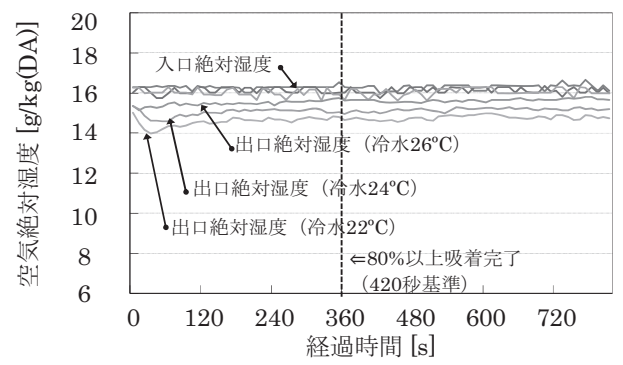

(a) 空気絶対湿度変化

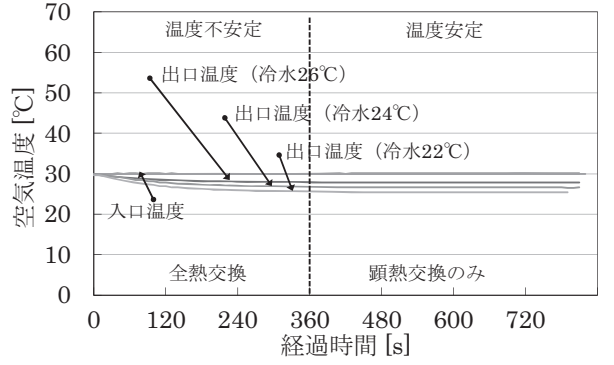

(b) 空気温度変化

図 8 空気冷却・水蒸気吸着モードにおける空気の温・湿度変化

※ 冷水流量 $0.50 \mathrm{~kg} / \mathrm{s}$ で, $30^{\circ} \mathrm{C}, 60 \% \mathrm{RH}$ の空気 $500 \mathrm{~m}^{3} / \mathrm{h}$ が供給された場合

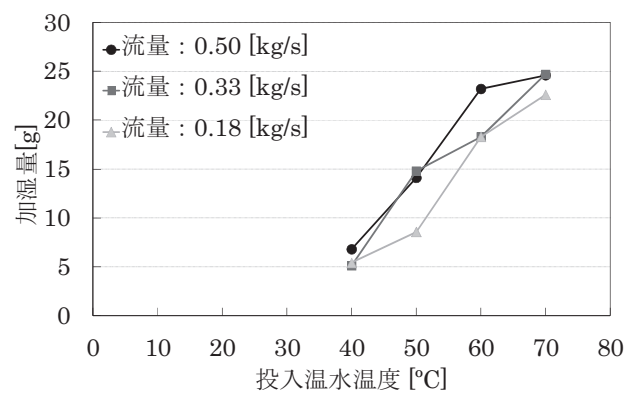

(a) 投入流量を変化させた場合の温水温度と加湿量の関係

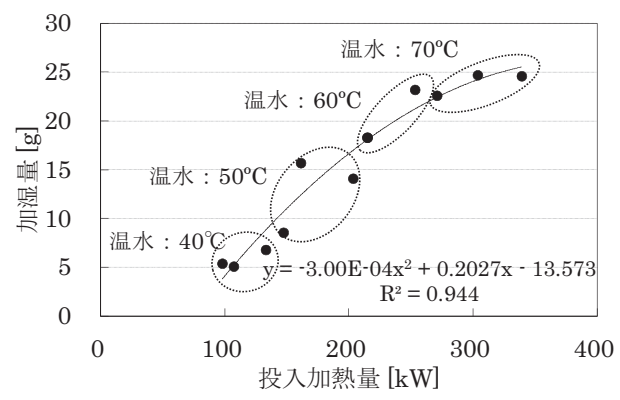

（b）投入加熱量と加湿量の関係（流量 $0.50 \mathrm{~kg} / \mathrm{s}$ ，一定）

図 9 熱源条件による水蒸気脱着量 (加湿量) の検討結果

※ 空気側条件 : $19^{\circ} \mathrm{C}, 65 \% \mathrm{RH}$ の空気 $500 \mathrm{~m}^{3} / \mathrm{h}$ が供給された場合
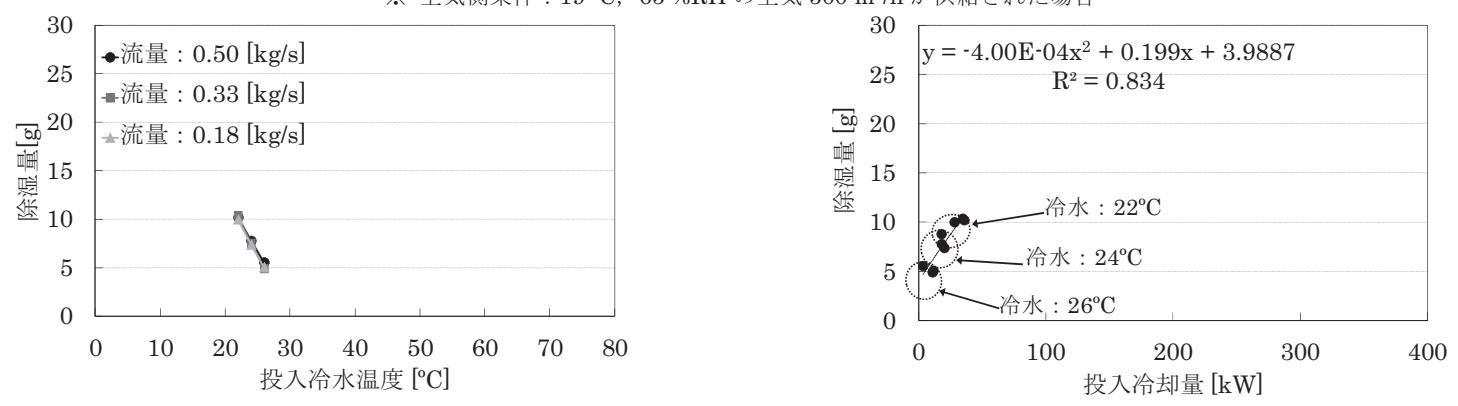

(a) 投入流量を変化させた場合の冷水温度と除湿量の関係

（b）投入冷却量と除湿量の関係（流量 $0.50 \mathrm{~kg} / \mathrm{s}$ ，一定）

図 10 熱源条件による水蒸気吸着量（除湿量）の検討結果

※ 空気側条件 : $30{ }^{\circ} \mathrm{C}, 60 \% \mathrm{RH}$ の空気 $500 \mathrm{~m}^{3} / \mathrm{h}$ が供給された場合 
投入する空気の湿度は, 冷却調湿装置の湿度制御により, 約 \pm 0.3

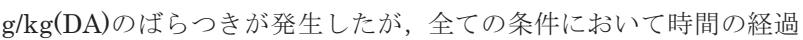
とともに水蒸気吸着量(除湿量) が徐々に減少寸る傾向が見られた。 水蒸気脱着の約 $80 \%$ 以上 (420 秒間の積分值基準) が経過時間 360 秒以内に行われた（図 8(a))。空気温度は吸着完了までには約 $2.0 \sim$ $4.5^{\circ} \mathrm{C}$ 低下した。以上の結果より, 提案システムのサーマルサイク ル（連続運転サイクル）は 360 秒が有効であると考えられる。また， 水蒸気吸・脱着量は時間経過とともに徐々に減少し, 投入熱量が大 きくなるほど吸・脱着完了時間が早くなることが確認された。

\section{（2）投入熱量による水蒸気吸・脱着特性}

図 9(a)に温水温度・流量と加湿量の関係を示す。加湿量は投入熱 量に大きく影響を受けることが確認された。図 9(b)に 420 秒間のデ 一夕の積分值を用いた投入熱量と加湿量の関係を示す。温水温度と 投入熱量が大きくなると加湿量が増えるが，温水温度 $50{ }^{\circ} \mathrm{C}$ で， 15 $\mathrm{g}$ 以上の加湿量を得られることが確認された。図 10 (a) に投入流量を 変化させた場合の冷水温度と除湿量の関係，図 $10(\mathrm{~b})$ に投入熱量に よる除湿量の検討結果を示す。除湿量は流量より冷水温度の変化に 敏感で, 泠水温度が低くなる（投入泠却熱量が大きくなる）と除湿 量が増加した。以上の結果から提案システムを構成した熱交換器の 調湿量は, 温・冷水流量より温・冷水温度の方がより大きな影響因 子であると判断される。また, 提案システムを構成した熱交換器の 場合, 比較的短時間での水蒸気吸・脱着特性が見られ, より少量の 吸着剤でシステムを構成することが可能であると考えられる。

\section{5. 外気温・湿度変化によるシステムの性能検討 5.1 実験概要}

実験は東京大学の生産技術研究所内にある極限環境試験室を用い て実施する。OA 側では極限環境試験室の温・湿度制御を行って一 定状態の外気を再現した。RA 側は実験準備室に設置されているエ アコンを用いて温度制御（設定温度 $20{ }^{\circ} \mathrm{C}$ ）をおこなう。表 2 に測 定項目, 測定機器, 測定点, 表 5 にはシステムの空気加熱・水蒸気 脱着モードにおける実験ケース (全 9 ケース), 表 6 にはシステム の空気冷却・水蒸気吸着モードにおける実験ケース（全 6 ケース） をそれぞれ示す。

熱源としては, ガスボイラーから作られた温水と泠却チラーから作 られた泠水を, 低温排熱からの温水とクーリングタワーからの泠水と して想定する。熱源条件は第 4 節の熱交換器の性能評価結果から最大 効果が得られる条件を基に設定する。提案システムのサーマルサイク ルの構成を図 11 に示す。吸・脱着現象の約 $80 \sim 90 \%$ 以が経過時 間 360 秒間以内に発生するため, サーマルサイクルは 375 秒の周期 (吸着・脱着時間 360 秒，サイクル準備時間 15 秒）に切り替える設 定とした。サイクル準備時間にはシステムの電動ダンパーと電動三方 弁を制御することで, 熱交換器を通過する空気経路と熱交換器に投入 される熱源水の経路を同時に切り替える。

空気加熱・水蒸気脱着モードにおける除湿側の泠水温度は $15^{\circ} \mathrm{C}$ で あり, 熱交換器表面の結露発生防止のために RA 空気の露点温度（基 淮 $\left.22.0^{\circ} \mathrm{C}, 50 \% \mathrm{RH}\right) 14^{\circ} \mathrm{Cdp}$ 以上の冷水温度を供給する。その一方 空気冷却・水蒸気吸着モードにおける除湿側の冷水温度は, 投入空気 の露点温度 $19.5 \sim 24.2^{\circ} \mathrm{Cdp}$ （表 6 ）以上の冷水温度を供給すべきで あるが, 熱交換器表面に塗布された吸着剂からの吸着熱により表面温

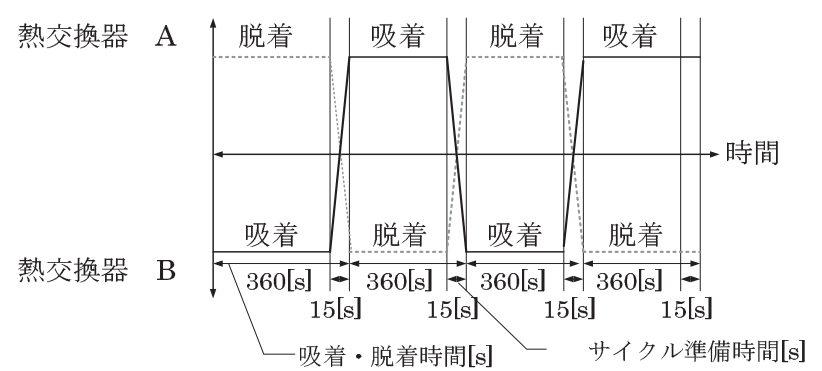

\section{電動ダンパー作動時間 [12s]}

電動三方弁作動時間 [15s]

図 11 提案システムのサーマルサイクル構成

表 5 空気加熱・水蒸気脱着モードの実験ケース

\begin{tabular}{c|c|c|c}
\hline ケース & $\mathrm{OA}$ 温度 & $\mathrm{OA}$ 相対湿度 & $\mathrm{OA}$ 絶対湿度 \\
\hline ケース $\mathrm{A}$ & $5.0{ }^{\circ} \mathrm{C}$ & $50 \% \mathrm{RH}$ & $3.0 \mathrm{~g} / \mathrm{kg}(\mathrm{DA})$ \\
\hline ケース $\mathrm{B}$ & $5.0{ }^{\circ} \mathrm{C}$ & $60 \% \mathrm{RH}$ & $3.4 \mathrm{~g} / \mathrm{kg}(\mathrm{DA})$ \\
\hline ケース $\mathrm{C}$ & $5.0{ }^{\circ} \mathrm{C}$ & $70 \% \mathrm{RH}$ & $3.8 \mathrm{~g} / \mathrm{kg}(\mathrm{DA})$ \\
\hline ケース $\mathrm{D}$ & $10.0{ }^{\circ} \mathrm{C}$ & $40 \% \mathrm{RH}$ & $3.0 \mathrm{~g} / \mathrm{kg}(\mathrm{DA})$ \\
\hline ケース $\mathrm{E}$ & $10.0{ }^{\circ} \mathrm{C}$ & $50 \% \mathrm{RH}$ & $3.8 \mathrm{~g} / \mathrm{kg}(\mathrm{DA})$ \\
\hline ケース $\mathrm{F}$ & $10.0{ }^{\circ} \mathrm{C}$ & $60 \% \mathrm{RH}$ & $4.5 \mathrm{~g} / \mathrm{kg}(\mathrm{DA})$ \\
\hline ケース $\mathrm{G}$ & $15.0{ }^{\circ} \mathrm{C}$ & $40 \% \mathrm{RH}$ & $4.2 \mathrm{~g} / \mathrm{kg}(\mathrm{DA})$ \\
\hline ケース $\mathrm{H}$ & $15.0{ }^{\circ} \mathrm{C}$ & $50 \% \mathrm{RH}$ & $5.3 \mathrm{~g} / \mathrm{kg}(\mathrm{DA})$ \\
\hline ケース $\mathrm{I}$ & $15.0{ }^{\circ} \mathrm{C}$ & $60 \% \mathrm{RH}$ & $6.3 \mathrm{~g} / \mathrm{kg}(\mathrm{DA})$ \\
\hline 熱源条件 & \multicolumn{3}{|c}{ 加湿側 $: 60{ }^{\circ} \mathrm{C}, 0.50 \mathrm{~kg} / \mathrm{s}$, 一定 } \\
\hline 風量 & $500 \mathrm{~m} / \mathrm{h}$, 熱交換器面風速 $1.32 \mathrm{~m} / \mathrm{s}$, 一定 \\
\hline
\end{tabular}

表 6 空気冷却・水蒸気吸着モードの実験ケース

\begin{tabular}{|c|c|c|c|}
\hline ケース & $\mathrm{OA}$ 温度（露点温度） & $\mathrm{OA}$ 相対湿度 & $\mathrm{OA}$ 絶対湿度 \\
\hline ケース 1 & $28.0^{\circ} \mathrm{C}\left(19.5^{\circ} \mathrm{Cdp}\right)$ & $60 \% \mathrm{RH}$ & $14.2 \mathrm{~g} / \mathrm{kg}(\mathrm{DA})$ \\
\hline ケース 2 & $28.0^{\circ} \mathrm{C}\left(22.0^{\circ} \mathrm{Cdp}\right)$ & $70 \% \mathrm{RH}$ & $16.7 \mathrm{~g} / \mathrm{kg}(\mathrm{DA})$ \\
\hline ケース 3 & $28.0^{\circ} \mathrm{C}\left(24.2^{\circ} \mathrm{Cdp}\right)$ & $80 \% \mathrm{RH}$ & $19.1 \mathrm{~g} / \mathrm{kg}(\mathrm{DA})$ \\
\hline ケース 4 & $30.0^{\circ} \mathrm{C}\left(21.4^{\circ} \mathrm{Cdp}\right)$ & $60 \% \mathrm{RH}$ & $16.0 \mathrm{~g} / \mathrm{kg}(\mathrm{DA})$ \\
\hline ケース 5 & $30.0^{\circ} \mathrm{C}\left(23.9^{\circ} \mathrm{Cdp}\right)$ & $70 \% \mathrm{RH}$ & $18.8 \mathrm{~g} / \mathrm{kg}(\mathrm{DA})$ \\
\hline ケース 6 & $33.0^{\circ} \mathrm{C}\left(24.2^{\circ} \mathrm{Cdp}\right)$ & $60 \% \mathrm{RH}$ & $19.1 \mathrm{~g} / \mathrm{kg}(\mathrm{DA})$ \\
\hline 熱源条件 & \multicolumn{3}{|c|}{$\begin{array}{l}\text { 加湿側 : } 60^{\circ} \mathrm{C}, 0.50 \mathrm{~kg} / \mathrm{s}, \text { 一定 } \\
\text { 除湿側 : } 22^{\circ} \mathrm{C}, 0.50 \mathrm{~kg} / \mathrm{s}, \text { 一定 } \\
\end{array}$} \\
\hline 風量 & \multicolumn{3}{|c|}{$500 \mathrm{~m}^{3} / \mathrm{h}$, 熱交換器面風速 $1.32 \mathrm{~m} / \mathrm{s}$, 一定 } \\
\hline
\end{tabular}

度が上がるため, 冷水温度を $22{ }^{\circ} \mathrm{C}$ までげて実験をおこなう。

\section{2 実験結果}

5.2.1 提案システムの連続運転による空気の温・湿度変化

(1) 空気加熱 - 水蒸気脱着モードにおける空気の状態変化

冬期の空気加熱・水蒸気脱着モードのケース A における外気 $(\mathrm{OA})$, 給気 $(\mathrm{SA})$, 還気 $(\mathrm{RA})$, 排気 (EA) 側の空気温度と絶 対湿度の測定結果を図 12 に示寸。 $\mathrm{OA}$ の平均温・湿度は $3.0{ }^{\circ} \mathrm{C}$, $85.0 \% \mathrm{RH}(4.0 \mathrm{~g} / \mathrm{kg}(\mathrm{DA}))$ であり, $\mathrm{RA}$ の平均温・湿度は $18.5{ }^{\circ} \mathrm{C}$, $42.0 \% \mathrm{RH}(5.5 \mathrm{~g} / \mathrm{kg}(\mathrm{DA}))$ であった。加湿側には $60.0^{\circ} \mathrm{C}$ の温水, 除湿側には $22.0^{\circ} \mathrm{C}$ 冷水を一定流量（ $\left.0.50 \mathrm{~kg} / \mathrm{s}\right)$ で投入した。 $\mathrm{OA}$ は加湿側の熱交換器を通過後, $60^{\circ} \mathrm{C}$ の温水と熱交換し, 平均して $35.5^{\circ} \mathrm{C}$ まで加熱される。さらに熱交換器への水分の脱着完了後に 
は, 約 $38.4{ }^{\circ} \mathrm{C}$ まで加熱されることが確認された。また, 湿度はサ 一マルサイクルによって熱交換器が除湿側から再生側に切り替わ った瞬間, 急激に吸着された水分が放出されることもあり, 絶対 湿度 $3.0 \mathrm{~g} / \mathrm{kg}(\mathrm{DA})$ の $\mathrm{OA}$ が最大 $7.2 \mathrm{~g} / \mathrm{kg}(\mathrm{DA})$, 平均 $4.4 \mathrm{~g} / \mathrm{kg}(\mathrm{DA})$ に加湿され供給された。RA は除湿側の熱交換器を通過した後, 温 度は平均して $2.3^{\circ} \mathrm{C}$ 上昇し, 湿度は $5.5 \mathrm{~g} / \mathrm{kg}(\mathrm{DA})$ から $3.8 \mathrm{~g} / \mathrm{kg}(\mathrm{DA})$

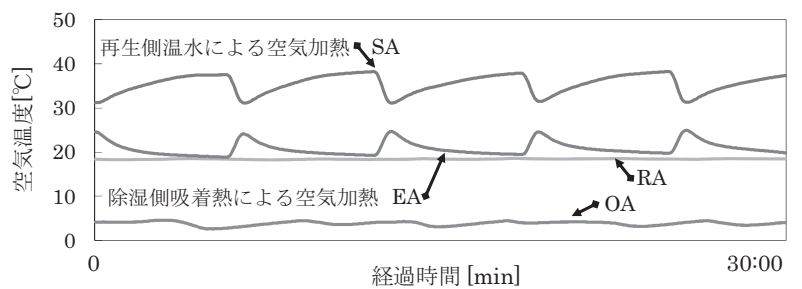

(a) 空気の温度変化

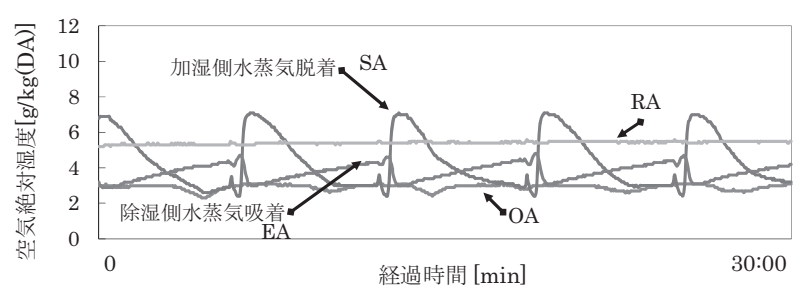

(b) 空気の絶対湿度变化

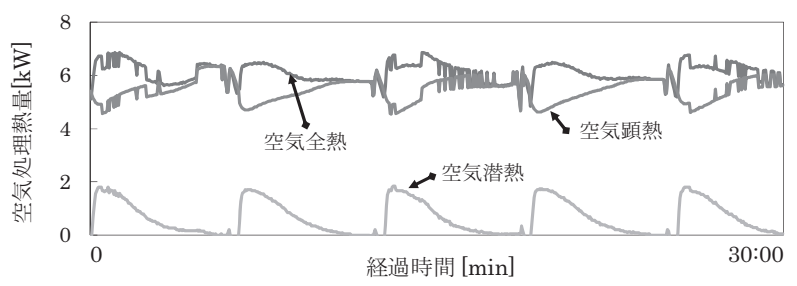

(c) $\mathrm{OA}$ 処理熱量
までに低下し, 熱交換器の吸着剂により水蒸気を回収した。空気 処理熱量は平均 $5.9 \mathrm{~kW}$ であり, 空気の顕・潜熱はシステムのサー マルサイクルにより変化することが確認された（図 12(c)）。

(2) 空気冷却・水蒸気吸着モードにおける空気の状態变化

空気冷却・水蒸気吸着モードのケース 6 における OA, SA, RA,

EA 側の空気温度と絶対湿度の測定結果を図 13 に示寸。OA の温・

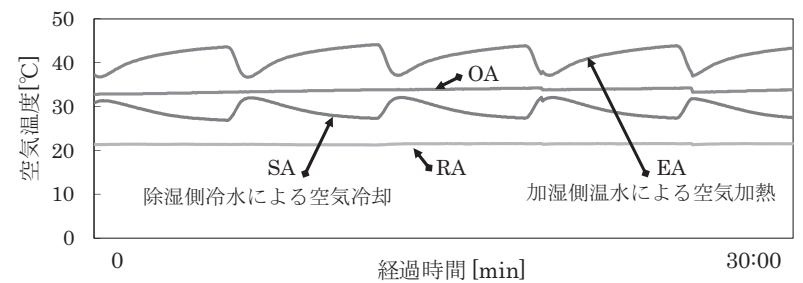

(a) 空気の温度変化

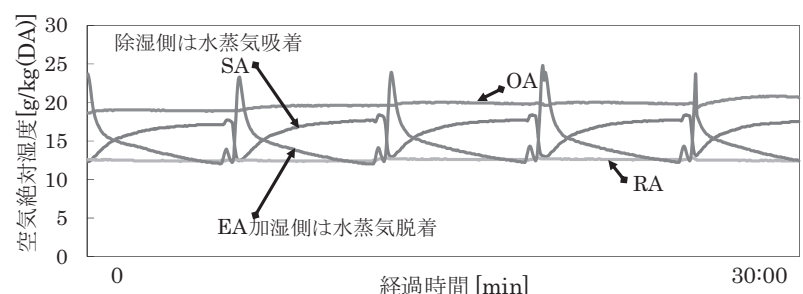

(b) 空気の絶対湿度変化

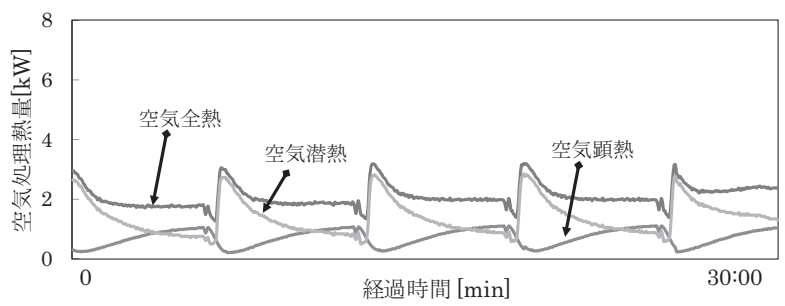

(c) OA 処理熱量

図 12 空気加熱・水蒸気脱着モードにおける空気状態変化 (ケース A) 図 13 空気冷却・水蒸気吸着モードにおける空気状態変化 (ケース 6)

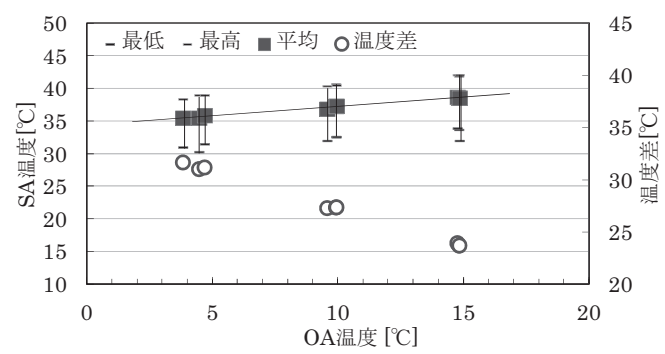

(a) OA 温度と SA 温度の関係

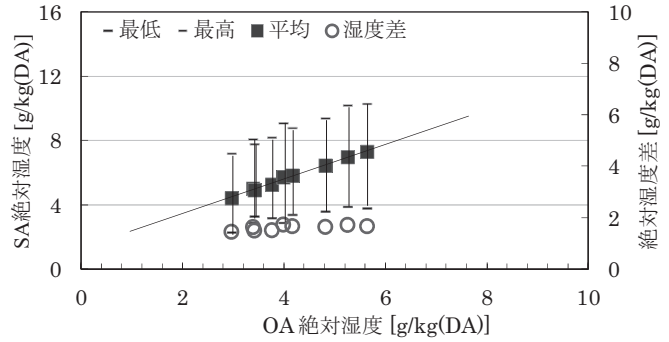

(b) OA 絶対湿度と SA 絶対湿度の関係

図 14 空気加熱・水蒸気脱着モードにおける $\mathrm{OA}$ と $\mathrm{SA}$ の関係

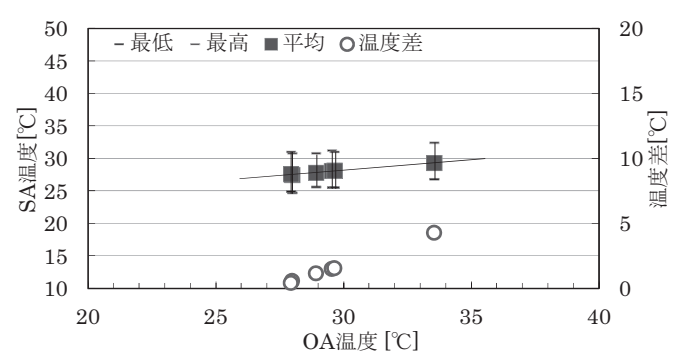

(a) OA 温度と SA 温度の関係

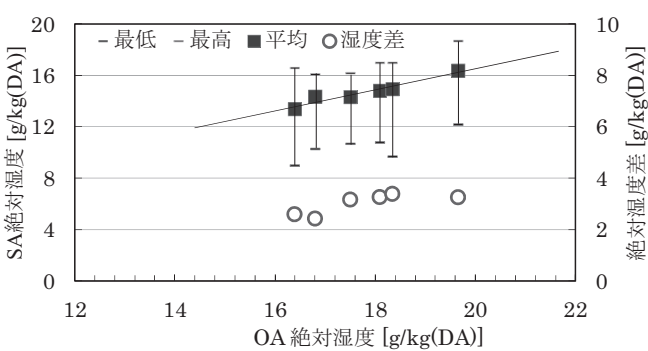

(b) $\mathrm{OA}$ 絶対湿度と $\mathrm{SA}$ 絶対湿度の関係

図 15 空気冷却・水蒸気吸着モードにおける $\mathrm{OA}$ と $\mathrm{SA}$ の関係 


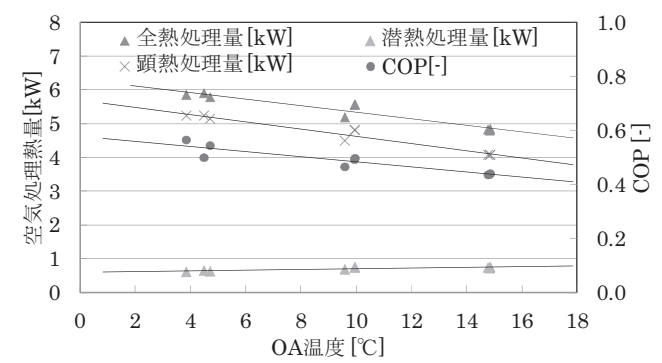

(a) $\mathrm{OA}$ 温度と空気処理熱量の関係

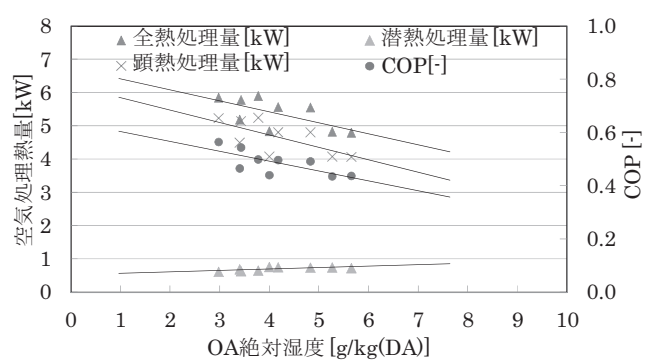

(b) OA 絶対湿度と空気処理熱量の関係

図 16 空気加熱・水蒸気脱着モードにおける OA と空気処理熱量および COP の関係

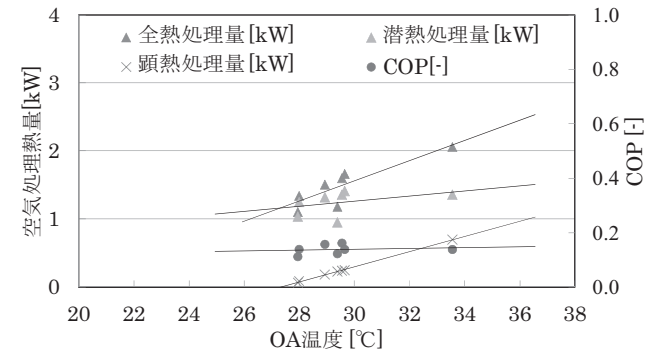

(a) OA 温度と空気処理熱量の関係

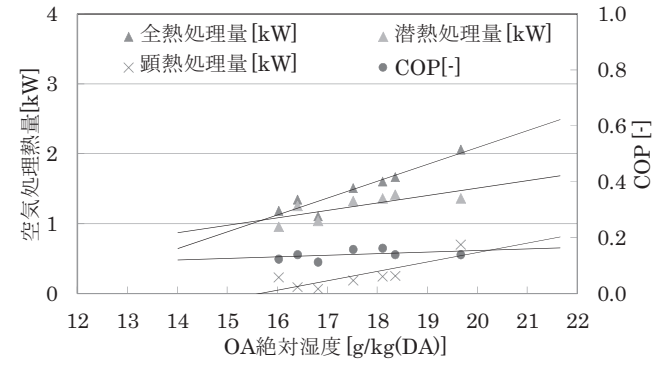

(b) $\mathrm{OA}$ 絶対湿度と空気処理熱量の関係

図 17 空気冷却・水蒸気吸着モードにおける OA と空気処理熱量および COP の関係

湿度は平均して $33.5{ }^{\circ} \mathrm{C}, 60.0 \% \mathrm{RH}(19.7 \mathrm{~g} / \mathrm{kg}(\mathrm{DA}))$ になり, $\mathrm{RA}$ の温・湿度は平均して $21.5{ }^{\circ} \mathrm{C}, 78.0 \% \mathrm{RH}(12.6 \mathrm{~g} / \mathrm{kg}(\mathrm{DA}))$ になっ た。除湿側には $22.0^{\circ} \mathrm{C}$ の泠水を $0.50 \mathrm{~kg} / \mathrm{s}$ の一定流量で投入した。 空気温度 $33.0^{\circ} \mathrm{C}$ の $\mathrm{OA}$ は $22.0^{\circ} \mathrm{C}$ の冷水と熱交換し, 平均して 29.3 ${ }^{\circ} \mathrm{C}$ まで泠却され, さらに熱交換器への水分の吸着完了後には約 26.8 ${ }^{\circ} \mathrm{C}$ まで泠却された。絶対湿度 $19.6 \mathrm{~g} / \mathrm{kg}(\mathrm{DA})$ の $\mathrm{OA}$ は最低 12.2 $\mathrm{g} / \mathrm{kg}(\mathrm{DA})$, 平均 $16.4 \mathrm{~g} / \mathrm{kg}(\mathrm{DA})$ に除湿され供給された。 $\mathrm{SA}$ の最低值 は夏季の室内空調設定条件（温度 $26.0{ }^{\circ} \mathrm{C}$, 相対湿度 $60.0 \%$, 絶対 湿度 $12.6 \mathrm{~g} / \mathrm{kg}(\mathrm{DA}))$ より低いため, 泠水の温度, サーマルサイク ル時間を改善すると外調機として安定的に除湿能力を発揮すること が可能であると考える。

\subsection{2 外気温・湿度と供給温・湿度の関係}

1 時間の連続運転の実験データから平均值を算出し, 図 14 に空気 加熱・水蒸気脱着モードにおける $\mathrm{OA}$ の温・湿度変化による $\mathrm{SA} の$ 温・湿度変化の関係を示す。 $\mathrm{OA}$ の温度 $\left(5.0,10.0,15.0^{\circ} \mathrm{C}\right)$ と温 水 $\left(60^{\circ} \mathrm{C}\right)$ の温度差が高くなるほど $\mathrm{OA}$ の温度と $\mathrm{SA}$ の温度差も高 くなっていることが確認された。それは高温の温水と低温の空気間 の温度差が高くなるほど, 移動する熱量が大きくなったからと考え られる。また, OA の温度が約 $15.0{ }^{\circ} \mathrm{C}$ (図 14(a)) に固定された場 合, 湿度が $4.8,5.3,5.6 \mathrm{~g} / \mathrm{kg}(\mathrm{DA})$ （図 14(b)）に高くなるほど SA の湿度も高くなった。

図 15 に空気冷却・水蒸気吸着モードにおける $\mathrm{OA}$ の温・湿度変 化による $\mathrm{SA}$ の温・湿度変化の関係を示す。OA の温度が高くなる と $\mathrm{OA}$ と $\mathrm{SA}$ の温度差が大きくなり空気への冷却効果が増加した。 これは, 空気と冷水の温度差が大きくなると熱移動が容易になるた めであると考える。また, 高湿度になると吸着剤が水分を吸着しや すくなった。これらの結果から, より少量の吸着剤でシステムを構 成すれば，短期間の連続運転によって外気を除湿・加湿できること
が明らかになった。

\section{2 .3 外気温・湿度と空気処理熱量および COP の関係}

図 16 に空気加熱・水蒸気脱着モードにおける OA の温・湿度と システムの空気処理熱量および成績係数（COP）の関係を示す。 熱源が一定の条件下で外気温・湿度を変化させた場合について考 察する。空気の全熱処理熱量は $\mathrm{OA}$ 温度が低くなると上昇した。 例えば図 16(a)で $\mathrm{OA}$ の温度が $5{ }^{\circ} \mathrm{C}$ の場合, 空気全熱処理熱量が 約 $5.9 \mathrm{~kW}$ (潜熱 $0.6 \mathrm{~kW}$, 顕熱 $5.2 \mathrm{~kW}$ ) となり，そのうち約 $88 \%$ が顕熱処理分であった。OAの湿度が高くなると空気潜熱処理熱量 が少し上がるが，加湿側に投入した熱エネルギーは殆ど空気の顕 熱処理に使用されたと考えられる。空気潜熱処理熱量はOA の温. 湿度変動による影響を殆ど受けず, 吸着剤からの水蒸気の脱着に 必要な熱と前段階のサーマルサイクルで吸着された水分量に影響 されると考えられる。COP を算出したところ，OA 温度が低下す ると COP は上昇し, 例えば $\mathrm{OA}$ 温度が $5{ }^{\circ} \mathrm{C}$ の場合, COP は 0.57 になった（図 16(a))。

図 17 に空気冷却・水蒸気吸着モードにおける OA の温・湿度と システムの空気処理熱量および成績係数 (COP) の関係を示す。温 度 $33.5^{\circ} \mathrm{C}$ の $\mathrm{OA}$ では空気全熱処理熱量が約 $2.1 \mathrm{~kW}$ (潜熱 $1.4 \mathrm{~kW}$, 顕熱 $0.7 \mathrm{~kW})$ になり，約 $67 \%$ が潜熱処理分であった。OAの温・ 湿度が高くなると空気全熱処理熱量も上昇したが，空気の顕熱比は $0.1 \sim 0.3$ であり，ほぼ全ての能力が空気潜熱処理に用いられた。し かし, サイクル準備時間 15 秒では空気経路の切り替えにより, 高 湿の加湿側の空気と低湿度の除湿側の空気が混合され除湿の効率が 低下寸ると考えられる。これらの問題は今後の解決す心゙き課題であ る。また, 加湿側の熱交換器を除湿側に使用すると, 加湿側で加熱 された熱量と装置の熱容量の影響を受けて, 除湿側の空気冷却性能 も抑制されたと考えられる。 


\section{6. まとめ}

本報では提案システムの精密な数值解析モデルを作成するため基 礎データを実験により取得した。実験は提案システム構成要素であ る吸着剂が塗布された熱交換器の特性を検討の上, 外気温・湿度の 変化による提案システムの空気加熱・水蒸気脱着モード, 空気冷却・ 水蒸気吸着モード性能の検討を行い以下の知見を得た。

1）提案システムを構成した熱交換器の調湿量に関しては, 温・冷 水流量より温・冷水温度の方がより大きな影響因子であること が分かる。

2）提案システムに投入された少量の吸着剂でも短時間のサーマル サイクル連続運転によって安定的に湿度制御をおこなえること が確認された。また, 空気加熱・水蒸気脱着モードでは冬期の低 温外気を $35{ }^{\circ} \mathrm{C}$ 以上まで加熱できるため, 暖房の補助システム として活用価值が高いと考えられる。

3) 空気加熱・水蒸気脱着モードに関して OA 温度が約 $5{ }^{\circ} \mathrm{C} \sim 15{ }^{\circ} \mathrm{C}$, $40 \sim 70 \% \mathrm{RH}$ の場合, 空気全熱処理能力は約 $4.8 \sim 5.9 \mathrm{~kW}$ であ り, 顕熱処理能力は $4.1 \sim 5.2 \mathrm{~kW}$ であり約 $88 \%$ 以上が顕熱処理 分である。加湿側の導入熱の大半が外気温の上昇，つまり顕熱 処理に使われた。空気冷却・水蒸気吸着モードに関して OA 温 度が約 $28.0 \sim 33.5{ }^{\circ} \mathrm{C}, 60 \sim 80 \% \mathrm{RH}$ の場合, 空気全熱処理能 力は約 $1.1 \sim 2.1 \mathrm{~kW}$ であり, 約 $67 \%$ 上が潜熱処理分である。 除湿側の導入熱の大半が外気の除湿, つまり潜熱処理に使用さ れた。

4) 提案システムの空気加熱・水蒸気脱着モード・空気椧却・水蒸 気吸着モードの性能は外気の温・湿度変動より, 投入熱量によ る大きく影響されると考えられる。

従って, 熱源有効利用の観点からシステム効率を向上させるため には熱源温度の最適設定が必要であると考えられる。また，今回の サーマルサイクル時間は， 6 min (360 秒) を想定しているがより 短期間の切り替えのサイクルによるシステムの性能検討および切り 替えのサイクルの最適化検討も必要であると考えられる。

以上の結果は, 今後提案システムの数值解析モデル作成の基礎デ ータとして活用できると考えられる。

\section{謝辞}

本研究は, (株) 東京ガスとの共同研究により取り組まれたもので あり, ここに記して謝意を表します。また，熱交換器の製作に関し まして, (株) 三菱樹脂の䆶川清一氏に多大な御協力と御指導を賜り ました。

\section{注}

注 1) 各換気方式：一般換気システム, 全熱交換器, ヒートポンプデシカ ントシステム，低温排熱を利用する提案システムとヒートポンプデシカ ントシステムを組み合わせた場合の四つの方式である。

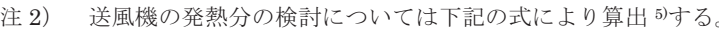
·送風機の動力負荷 $[\mathrm{kW}]$

$$
\mathrm{W}_{F}=\frac{(Q \times \mathrm{SP})}{\left(3600 \times 1000 \times \eta_{\mathrm{F}} \times \eta_{\mathrm{M}}\right)}
$$

・送風機による温度上昇值 $\left[{ }^{\circ} \mathrm{C}\right]$

$$
\Delta t_{a}=\frac{W_{F}}{\rho_{\text {air }} \times Q} \times 3600
$$

ここに, $W_{F}$ は送風機の動力負荷 $\left[\mathrm{kW}, Q\right.$ は風量 $\left[\mathrm{m}^{3} / \mathrm{h}\right], \mathrm{SP}$ は送風機静 圧 $[\mathrm{Pa}]$ (ここでは $500\left[\mathrm{~m}^{3} / \mathrm{h}\right]$ の場合は $170[\mathrm{~Pa}], 250\left[\mathrm{~m}^{3} / \mathrm{h}\right]$ の場合は $200[\mathrm{~Pa}]$

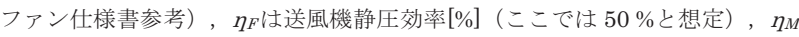
は電動機効率[\%]（ここでは $90 \%$ と想定）， $\Delta t_{a}$ 送風機による温度上昇值, $\rho_{\text {air }}$ は空気の密度 $\left[\mathrm{kg} / \mathrm{m}^{3}\right]$ である。送風機による温度上昇值の算出結果，500 $\left[\mathrm{m}^{3} / \mathrm{h}\right]$ の場合は $0.3\left[{ }^{\circ} \mathrm{C}\right], 250\left[\mathrm{~m}^{3} / \mathrm{h}\right]$ の場合は $0.37\left[{ }^{\circ} \mathrm{C}\right]$ 温度が上昇した。

\section{参考文献}

1）朴炳龍, 李時桓, 加藤信介：コジェネレーション排熱利用バッチ式デシカ ント外気処理システムの開発，エネルギーシミュレーションによる開発シ ステムの適用可能性検討 (その 1), 日本建築学会環境系論文集第 77 巻第 678 号, pp.671-680, 2012.8

2) 垣内博行, 下岡里美, 岩出美紀, 大島一典, 山崎正典, 寺田秀, 渡辺展, 武脇隆彦: 新規水蒸気吸着材 FAM-Z01 の基礎特性評価および吸着ヒート ポンプへの適応性検討, 化学工学論文集, 第 31 巻, 第 5 号, pp.361-364, 2005.9

3）高顕熱型ビル用マルチ:デシカシステムカタログ(http://ec.daikinaircon. com/ecatalog/DKCB010/index.html), 2012.06.06 参照

4）日本全熱交換器 JIS B 8628，日本工業規格，2003.3

5）空気調和衛生工学会：徹底マスター空気線図の読み方・使い方，オーム社 発行, 2007.2

(2012年 7 月 10 日原稿受理，2013年 3 月 21 日採用決定） 